\title{
Konsentrasi Spermatozoa Burung Parkit (Melopsittacusundulatus) pada Berbagai Frekuensi Penampungan
}

\author{
Spermatozoa Concentration of Parakeets \\ (Melopsittacusundulatus) at Various Frequency \\ of Shelter
}

\author{
Nurkholis \\ Jurusan Peternakan Politeknik Negeri Jember \\ Jalan Mastrip Kotak Pos 164 Jember \\ azzam_mirzakholis@rocketmail.com
}

\begin{abstract}
This study was conducted from 6 to 12 November 2000 in Reproduction Laboratory of Animal Husbandry Faculty. The purpose of this study was to know difference of parakeet spermatozoa concentration in variation of collecting frequency level. The result is hoped useful in giving information about collecting frequency level hold for a week. The material use were 3 adult male parakeet took their semen during a week for three times collection by interval to days. The method was complete randomized design. The treatments were comparing spermatozoa concentration of the adult male parakeet in variation of collecting frequency level. The data obtained were analyzed by Duncan Multiple Range Test (DMRT). The result of study showed that spermatozoa spermatozoa concentration rate of different level for

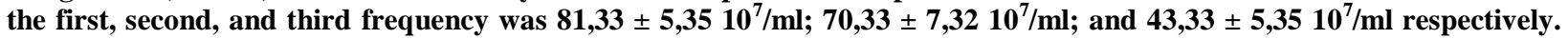
There was significant different effect $(P<0,01)$ in collection frequency level on the spermatozoa concentration. The result of DMRT showed that the fist and second collecting was similar but unsimilar to the third. The conclusion of this study was the collecting frequency gives significant effect $(P<0,01)$ on the spermatozoa concentration of the parakeet. The first and second collecting has no significant effect on the spermatozoa concentration, so that it is considerable that the optimal number of collecting for the semen of the parakeet was twice a week.
\end{abstract}

Keywords : parakeet, frequency and spermatozoa

\section{PENDAHULUAN}

Di Indonesia terdapat beraneka ragam burung hias yang dipelihara atau berkembang, salah satunya adalah burung parkit.Usaha pembudidayaan burung parkit di Indonesia masih belumbanyak dilakukan, hal ini dimungkinkan karena sedikitnya informasi mengenai system pemeliharaan serta nilai ekonomi yang dimiliki.

Beternak parkit dapat dilakukan dengan berbagai pola sebagai hiburan, kesenangan, kebanggaan dan sebagai sumber penghasilan yang bersifat sampingan maupun penghasilan pokok.Dharmojono (1996) berpendapat bahwa memelihara burung parkit dapat diusahakan menjadi bisnis besar dan berkesinambungan, karena mempunyai potensi ekonomi yang tinggi dan dapat menampung tenaga kerja. Wendrato dan Madyana (1990) mengemukakan bahwa harga burung parkit cukup menarik dan pemeliharaannya tidak sulit, karena pakan dan sarana lain mudah diperoleh, serta kondisi alam Indonesia yang mendukung sebab tidak berbeda jauh dengan kondisi alam dimana burung parkit berasal.

Burung parkit yang ada saat ini merupakan hasil penjinakan jenis parkit liar di Australia, dengan nama latin Melopsittatus undulatus. Habitat burung ini biasanya di daerah gurun berbatu-batu dan padang rumput, di dareah tropis dan sub tropis (Whendrato dan Madyana, 1990).

Keberhasilan usaha peternakan bertumpu pada tiga komponen dasar yakni, pakan, manajemen pemeliharaan, dan breeding. Pemeliharaan yang 
Nurkholis. Konsentrasi Spermatozoa Burung Parkit (Melopsittacusundulatus) Pada Berbagai Frekuensi Penampungan

mengarah pada breeding memerlukan pemilihan teliti dan terencana terhadap parkit yang akan dibiakkan. Proses breedingakan berjalan sempurna apabila ditunjang dengan tatalaksan reproduksi yang baik. Keberhasilan reproduksi merupakan kunci utama dari usaha peternakan.Kegagalan reproduksi kebanyakan disebabkan oleh kurangnya perhatian yang terus menerus terhadap ternak yang dipelihara.

Burung parkit memiliki keunikan dalam siklus reproduksi, dimana proses reproduksinya melalui penjodohan dan burung parkit ini terkenal setia pada pasangannya (monogami). Pada kasus tertentu burung parkit yang sudah lama dipasangkan tidak mau apabila dipasangkan/dijodohkan dengan yang baru. Hal inilah yang menjadi salah satu faktor yang dapat menurunkan produktifitas burung parkit.

Usaha meningkatkan produktifitas burung parkit dapat melalui implementasi teknologi reproduksi.Inseminasi Buatan (IB) merupakan teknologi reproduksi yang popular dilakukan dalam membantu peningkatan reproduksi ternak, khususnya ternak yang termasuk dalam kelas aves.

Keberhasilan pelaksanaan IB tergantung pada teknik penampungan, penilaian, penyimpanan dan penyampaian pada waktu dan tempat yang sesuai dengan reproduksi hewan betina. Penilaian terhadap kualitas dan kuantitas semen mendapat perhatian lebih, karena faktor inilah yang menjadi poin besar dalam menentukan keberhasilan IB.Berdasarkan penjelasan tersebut maka diperlukan adanya penelitian tentang karakteristik semen yang meliputi konsentrasi spermatozoa, volume, dan sifat fisik semen (komponen penilaian kualitas dan kuantitas semen) dari frekuesi penampungan yang berbeda pada burung parkit.

\section{Rumusan masalah}

Apakah ada perbedaan karakteristik semen terutama konsentrasi spermatozoa burung parkit pada berbagai tingkat frekuensi penampungan.

\section{Tujuan}

Penelitian ini bertujuan untuk mengetahui perbedaan konsentrasi spermatozoa burung parkit pada berbagai frekuensi penampungan.

\section{Manfaat}

Hasil penelitian ini diharapkan dapat digunakan untuk bahan pertimbangan di dalam menentukan frekuensi penampungan semen yang baik sehingga dapat menunjang keberhasilan IB, dan akhirnya mampu meningkatkan mutu genetik dan populasi burung parkit

\section{Materi dan Metode}

Tempat dan Waktu Penelitian
Penelitian ini dimulai pada tanggal 06 sampai 12 November 2000, pengamatan semen dilakukan di laboratorium Reproduksi Fakultas Peternakan Universitas Brawijaya.

\section{Materi}

A. Hewan Penelitian

Penelitian ini menggunakan sampel semen yang berasal dari 3 ekor burung parkit jantan berumur \pm 7 bulan.Pemeliharaan burung parkit dilakukan dengan menempatkan dalam sangkar.Pemberian pakan disesuaikan pada keadaan, kebiasaan, dan aktivitas burung parkit.Pakan dan air minum diberikan secara ad libitum, penggantian air minum dilakukan setiap hari. Jenis pakan yang diberikan umumnya berbentuk butiran misalnya, millet, juwawut, dan sayuran segar (jagung muda, sawi, dan kangkung).

\section{B. Alat dan Bahan Penelitian}

Peralatan yang digunakan dalam penelitian ini adalah spuit $1,0 \mathrm{ml}$, tabung reaksi, cover glass, mikroskop, dan haemocytometer. Sedangkan bahan yang digunakan meliputi semen burung parkit, $\mathrm{NaCl}$ Fisiologis 3\%, dan Aquadest.

\section{METODOLOGI PENELITIAN}

Pengambilan Semen

Pengambilan atau penampungan semen burung parkit jantan menggunakan metode pemijatan (massage).Penampungan semen dalam satu minggu dilakukan sebanyak tiga kali dengan selang waktu dua hari untuk setiap penampungan. Burung parkit jantan sebelum diambil semennya terlebih dahulu dilatih supaya mudah dalam proses pengambilan semen. Tahapan dalam pengambilan semen pada burung parkit jantan dengan teknik pemijatan adalah sebagai berikut:

Burung parkit dipegang dengan tangan kiri, sedangkan tangan kanan memijat bagiat punggung secara ritmik, kemudian berpindah pada bagian caudal tepat di bawah tulang pubis, secara cepat dan kontinyu sampai papillae keluar dari kloaka, sementara ekor dijepit dengan tangan kiri. Semen yang keluar ditampung dengan cara menghisap dengan memakai spuit yang sebelumnya ditambahkan larutan $\mathrm{NaCl} 3 \%$ sebanyak $0,2 \mathrm{ml}$.

Penentuan warna dan volume semen yang ditampung dapat langsung dilakukan dengan cara melihat dan membaca skala pada spuit yang digunakan untuk menghisap semen. Penentuan konsentrasi semenbertujuan untuk menghitung jumlah sperma yang terdapat dalam semen dengan bantuan alat haemocitometer. Prosedur perhitungannya adalah sebagai

berikut: 
Pipet eritrosit diisi semen yang telah ditambahakan $\mathrm{NaCL}$ fisiologis 3\% dihisap sampai tanda 1,01 pada pipet. Campuran dikocok sampai $2-3$ menit, beberapa tetes dibuang dan dikocok lagi.Diteteskan setetes larutan spermatozoa dari pipet tepat dipinggir gelas penutup pada kamar hitung sel darah merah menurut Neubauer.Sel spermatozoa dalam 5 kamar dihitung menurut arah diagonal. Jika dalam kelima kotak $=$ X maka konsentrasi sperma $X \times 10^{7} / \mathrm{ml}$ semen.

\section{Analisis Anova}

Rancangan penelitian yang digunakan adalah Rancangan Acak Lengkap (RAL) dengan menggunakan 3 perlakuan dengan 3 ulangan. Perlakuannya adalah:

Perlakuan I: penampungan semen ke satu pada hari pertama. Perlakuan II: penampungan semen ke dua pada hari ke empat. Perlakuan III: penampungan semen ke tiga pada hari ke tujuh.

Penampungan ke satu, ke dua, dan ke tiga dilakukan selama satu minggu dengan interval 2 hari untuk masing-masing perlakuan.

Hasil yang diperoleh dari perhitungan dianalisi dengan sidik ragam.Jika hasil analisis tersebut menunjukkan adanya perbedaan antar perlakuan, maka dilanjutkan dengan Uji Jarak Berganda Duncan.

Persamaan umum model liniernya:

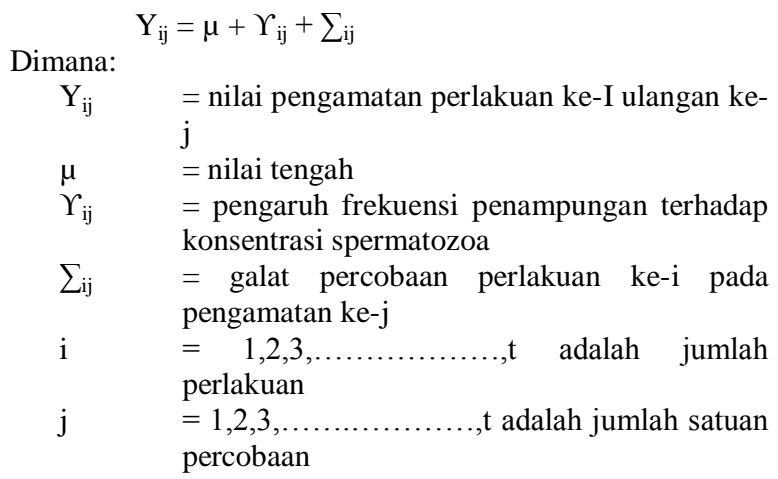

Faktor Koreksi $(\mathrm{FK})=\mathrm{Y}^{2} / \mathrm{rt}$

Jumlah Kuadrat Total $(\mathrm{JKT})=\sum_{\mathrm{ij}} \mathrm{Y}_{\mathrm{ij}}^{2}-\mathrm{FK}$

Jumlah Kuadrat Perlakuan (JKP)

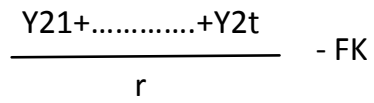

Jumlah Kuadrat Galat $(\mathrm{JKG})=\mathrm{JKT}-\mathrm{JKP}$

\section{III.HASIL DAN PEMBAHASAN}

\section{Karakteristik Semen}

Semen merupakan zat cair yang dikeluarkan oleh tubuh melalui saluran reproduksi hewan jantan, dimana semen terdiri atas suspensi semigelatinous yang berisi spermatozoa yang secara normal diejakulasikan ke dalam saluran reproduksi betina sewaktu kopulasi. Karakteristik semen yang diamati dalam penelitian ini meliputi karakteristik fisik dan konsentrasi spermatozoa.

\section{$\underline{\text { Karakteristik fisik semen burung parkit }}$}

Pengamatan karakteristik semen burung parkit terdiri atas volume dan warna. Hasil penampungan semen burung parkit pada berbagai frekuensi menunjukkan volume yang tidak nyata, dimana ratarata volume yang dihasilkan sebanyak $\pm 0,01 \mathrm{ml}$. Banyak sedikitnya volume semen dipengaruhi oleh bangsa dari ternak.

Tidak berbedanya volume semen dari setiap penampungan diduga karena jumlah semen yang ditampung cukup sedikit, sehingga dapat mempengaruhi dalam keakuratan dalam penilaian.Lamming (1984), menyatakan bahwa volume semen pada bangsa burung relatif sedikit tetapi memiliki kekentalan spermatozoa (4.000 $7.000 \mu \mathrm{l}^{-1}$ ) lebih besar dari mamalia. Sedangkan Phillips, et. al. (1985), menyatakan bahwa volume semen pada burung berkisar 50 - 200 $\mu 1 /$ jakulasi.Disamping itu, dalam penampungan semen dengan teknik pemijatan yang tidak dilakukan dengan hati-hati akan dapat menyebabkan sekresi tinggi cairan transparen dari lipatan-lipatan lymphe proctodaeum dan daerah vascular dekat pangkal vasa deferentia, dimana kehadirannya tidak dapat dihindarkan dalam semen yang ditampung (Toelihere, 1993).Banyak sedikitnya volume semen yang dihasilkan tidak mempengaruhi kualitas atau daya fertil dari spermatozoa.

Volume semen penting kaitannya dalam menentukan besar kecilnya tingkat pengenceran. Volume semen yang besar tentunya akan lebih banyak jumlah pengenceran dan secara langsung semakin banyak pula jumlah hewan betina yang dilayani (IB) dari hasil satu ejakulasi.

Warna normal semen pada hewan jantan dapatcukup bervariatif yakni putih susu, putih kekuningan, dan putih keabu-abuan (putih keruh). Selama penampungan semen pada burung parkit dihasilkan warna putih keruh.Warna memiliki korelasi/hubungan dengan volume semen yang dihasilkan. Volume semen yang besar memiliki kecenderungan dengan warna semen lebih terang, dan sebaliknya apabila volume semen sedikit akan memiliki warna semen yang keruh.

Pemeriksaan warna pada semen yang dihasilkan bertujuan dalam melakukan penilaian awal secara makroskopis pada kualitas semen.Semen 
Nurkholis. Konsentrasi Spermatozoa Burung Parkit (Melopsittacusundulatus) Pada Berbagai Frekuensi Penampungan

dengan warna yang menyimpang dapat disimpulkan bahwa semen telah terkontaminasi dengan bahan yang dapat mempengaruhi kualitas spermatozoa.Pada beberapa kasus tertentu dapat ditemui semen berwarna merah yang menandakan semen telah terkontaminasi darah yang berasal dari saluran kelamin/reproduksi (Toelihere, 1993).

Pengamatan warna semen dapat dilakukan dengan melihat langsung pada tabung penampung sesaat setelah semen diejakulasikan oleh burung parkit jantan.

Morfologi spermatozoa burung parkit memiliki kemiripan/kesamaan dengan morfologi spermatozoa pada kelas aves lainnya termasuk pada ungags. Secara umum morfologi spermatozoa tersusun atas kepala dan ekor serta dikelilingi oleh membrane plasma.Kepala sperma berbentuk silindris panjang dan acrosome yang runcing, gambar sperma burung parkit dapat dilihat pada gambar 1.Pada kepala spermatozoa terdapat bagian penting yakni inti yang mengandung materi genetic (DNA), yang $60 \%$ bagian anterior tertutup selubung akrosom yang memiliki struktur seperti kantong berdinding rangkap (Hafez, 2000).

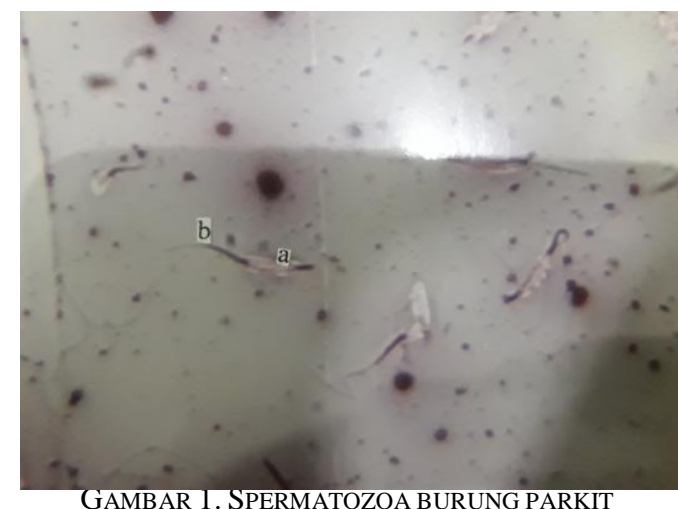

KETERNAGAN, A).BAGIAN KEPALA SPERMATOZOA, B).BAGIAN EKOR SPERMATOZOA.

\section{Konsentrasi Spermatozoa Burung Parkit pada Frekuensi Berbeda}

Konsentrasi spermatozoa burung parkit dihitung dengan menggunakan alat bantu berupa haemocytometer. Hasil perhitungan menunjukkan bahwa penampungan ke satu $(\mathrm{P} 1)$ memiliki nilai rataan tertinggi dari penampungan ke dua (P2) serta ke tiga (P3), dan $\mathrm{P} 2$ memiliki rataan tertinggi dibandingkan P3 (P1>P2>P3).Pengaruh frekuensi penampungan terhadap konsentrasi spermatozoa dapat dilihat pada tabel 1 .
TABEL 1. RATAAN KONSENTRASI SPERMATOZOA BURUNG PARKIT PADA BERBAGAI PENAMPUNGAN

\begin{tabular}{cc}
\hline Perlakuan & $\begin{array}{c}\text { Kisaran Konsentrasi } \\
\text { Spermatozoa }\left(\mathbf{X} . \mathbf{1 0}^{\mathbf{7}}\right) / \mathbf{m l}\end{array}$ \\
\hline P1 & $81,33 \pm 5,35$ \\
P2 & $70,33 \pm 7,32$ \\
P3 & $43,33 \pm 5,35$ \\
\hline
\end{tabular}

Dari tabel diatas dapat dijelaskan bahwa penampungan dengan frekuensi yang berbeda menghasilkan konsentrasi spermatozoa yang berbeda pula. Frekuensi penampungan yang sering (P3) akan menghasilkan konsentrasi spermatozoa yang rendah jika dibandingkan dengan konsentrasi spermatozoa hasil penampungan frekuensi penampungan sebanyak P2 dan P1. Hal ini sesuai pendapat Hafez (2000), ejakulasi pertama akan mempunyai spermatozoa tinggi dibandingkan dengan ejakulasi berikutnya. Hubungan antara frekuensi penampungan dengan konsentrasi penampungan dapat dilihat pada gambar 2

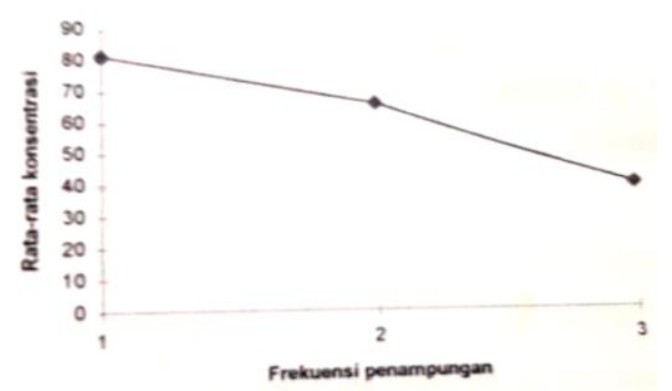

GAMBAR 2.HUBUNGAN FREKUENSI PENAMPUNGAN DENGAN KONSENTRASI SPERMATOZOA.

Dari gambar 2 di atas dapat dijelaskan bahwa hubungan antara frekuensi penampungan dengan konsentrasi semen memiliki bentuk hubungan/korelasi negatif, artinya apabila terjadi kenaikan pada satu sifat akan diikuti oleh turunnya sifat yang lain. Semakin sering burung parkit jantan ditampung semennya maka akan diikuti oleh turunnya konsentrasi spermatozoa.

Untuk mengetahui adanya pengaruh frekuensi penampungan terhadap konsentrasi spermatozoa burung parkit maka dilakukan analisis sidik ragam. Hasil analisis sidik ragam menunjukkan bahwa frekuensi penampungan memberikan pengaruh sangat nyata terhadap konsentrasi spermatozoa $(\mathrm{P}<0,01)$.

Konsentrasi spermatozoa hewan jantan dapat dipengaruhi oleh beberapa faktor, salah satunya adalah frekuensi penampungan.Konsentrasi spermatozoa menjelaskan jumlah spermatozoa dalam 
per milliliter cairan seminal plasma.Konsentrasi spermatozoa dapat menggambarkan tingkat kesuburan dari seekor hewan jantan.Selain volume konsentrasi spermatozoa juga digunakan dalam menentukantingkat pengenceran yang dilakukan pada semen hasil ejakulasi.

Perhitungan dilanjutkan dengan uji lanjut UJBD karena setiap perlakuan memberikan pengaruh yang sangat nyata terhadap konsentrasi spermatozoa.Hasil Uji Jarak Berganda Duncan tertera pada tabel 2.

TABEl 2. HaIl UJi JARAK BERGANDA DUNCAN

\begin{tabular}{ccc}
\hline Perlakuan & $\begin{array}{c}\text { Rerata } \\
(\mathbf{X . 1 0 7}) / \mathbf{m l}\end{array}$ & Notasi \\
\hline P1 & 81,33 & $\mathrm{a}$ \\
P2 & 70,33 & $\mathrm{a}$ \\
P3 & 43,33 & $\mathrm{~b}$ \\
\hline
\end{tabular}

Berdasarkan hasil UJBD antara P1 dan P2 tidak berbeda akan tetapi P1 dan P2 berbeda dengan P3. Hal ini menjelaskan bahwa frekuensi penampungan ke satu dan penampungan ke dua tidak mempengaruhi konsentrasi spermatozoa per ejakulasi, akan tetapi konsentrasi spermatozoa akan terpengaruh pada frekuensi ke tiga. Frekuensi penampungan yang berlebihan akan menurunkan kualitas semen, sehingga testes sebagai organ yang memproduksi semen memerlukan masa istirahat. Biasanya akan dihasilkan jumlah spermatozoa banyak setelah pengistirahatan sexual (Hafez, 2000).

Dari hasil di atas maka, penampungan semen pada burung parkit sebaiknya dilakukan dua kali dalam satu minggu. Hafez (2000) menyatakan bahwa ungags yang ditampung dua kali per minggu akan memberikan kualitas yang baik tanpa mempengaruhi jumlah volume dan konsentrasi spermatozoa.

\section{KESIMPULAN}

Frekuensi penampungan semen pada berbagai tingkat memberikan perbedaan yang sangat nyata $(\mathrm{P}<0,01)$ terhadap konsentrasi spermatozoa burung parkit. Penampungan ke satu serta ke dua memiliki jumlah spermatozoa yang sama dan lebih tinggi dibandingkan dengan penampungan ke tiga.

\section{SARAN}

Berdasarkan kesimpulan di atas, sebaiknya frekuensi penampungan semen burung parkit dilakukan sebanyak dua kali, hal ini untuk menjaga jumlah spermatozoa yang dihasilkan tiap ejakulasi memenuhi standart dalam perlakuan berikutnya.

\section{DAFTAR PUSTAKA}

[1] Bearden, H.J., and J.W., Fuquay, 1984. Applied Animal Reproduction. Second Edition. Reston Publishing Company. Inc. A. Prentice-Hall Company Reston. Virginia.
[2] Christian, M.S., 1984. Budgerigers; All you need know. Rigby Publishers. Sydney.

[3] Dharmojono, 1996. Aneka Permasalahan Burung dan Ayam Hias beserta Pemecahannya. PT. Penebar Swadaya. Jakarta.

[4] Hafez, E.S.E., 2000. Semen Evaluation; E.S.E., Hafez Editor. Reproductiaon in Farm Animal. $6^{\text {th }}$ Edition. Lea and Febiger. Philadelphia.

[5] Lohr, J.E., 1991. Your FirstBudgerigar. By. T.F.H., Publication. Inc. Neptune. USA.

[6] Nalbandov, A.V., 1990. Fisiologi dan Reproduksi pada Mamalia dan Unggas. Fisiologi Komparatif pada Hewan Domestik dan Laboratorium serta Manusia. Penerbit. Universitas Indonesia. Jakarta.

[7] Phillips, J.G., P.J. Butler and P.J. Sharp. 1985. Physiological Strategies in Avian Biology. Printed in Great Britain by Beil and Bain Ltd. New Delhi.

[8] Sastrodihardjo, S., dan H., Resnawati, 1999. Inseminasi Buatan pada Ayam Buras. Penerbit. PT. Penebar Swadaya. Jakarta.

[9] Sopandi, E.K., 1986. Mengenal dan Beternak Burung Parkit. Penerbit. PT. Karya Nusantara. Jakarta.

[10] Whendrato, I., dan I.M. Madyana, 1990. Budidaya Burung Parkit. Penerbit. Eka Offset. Semarang.

[11] Widodo, W., 1990. Parkit. Penebar Swadaya. Jakarta. 